\title{
ANALISIS PERSEPSI HARGA, KUALITAS PELAYANAN, CUSTOMER RELATIONSHIP MARKETING, DAN KEPERCAYAAN TERHADAP PENINGKATAN PENJUALAN DIMEDIASI LOYALITAS PELANGGAN PADA UMKM AYAM POTONG ONLINE ELMONSU
}

\author{
Abid Muhtarom \\ Univesitas Islam Lamongan \\ abid@unisla.ac.id

\section{Imam Syairozi} \\ Universitas Islam Lamongan \\ imamsyairozi@unisla.ac.id

\section{Nuriyah Dita Wardani \\ Universitas Islam Lamongan \\ nuriyahwardani@gmail.com}

\begin{abstract}
Abstrak
Pada era 4.0 persaingan dalam dunia usaha semakin tinggi, semua pelaku usaha berlomba-lomba untuk meningkatkan penjualan usahanya. usaha mikro, kecil dan menengah misalnya. Banyaknya usaha yang dibangun akan menimbulkan permasalahan yang pasti dialami setiap pelaku usaha, Kebaruan dari penelitian ini adalah terdapat variabel yang lebih banyak untuk diteliti. Jenis penelitian ini adalah pendekatan Kuntitatif dengan jumlah sampel 131 dan metode yang digunakan untuk menganalisis yaitu SEM dengan alat Smart PLS versi 3.0. uji yang digunakan adalah uji Outer Model, Uji Inner Model, Uji Mediasi dan Uji Hipotesis. Berdasarkan hasil uji Validitas menunjukkan bahwa nilai Loading Faktor leboih dari 0,7 dan nilai AVE lebih dari 0,5 dinyatakan valid, pada uji Reliabilitas nilai Composite Reliability dan Cronbach's Alpha diatas 0,7 dikatakan Reliable. Dapat disimpulkan bahwa variabel Customer Relationship Marketing (X3) dan kepercayaan (X4) berpengaruh positif secara signifikan terhadap peningkatan penjualan (Y).Variabel persepsi harga (X1) berpengaruh negatif dan signifikan terhadap peningkatan penjualan (Y). Sedangkan kualitas pelayanan (X2) berpengaruh negatif dan tidak signifikan terhadap peningkatan penjualan (Y). Dalam uji Mediasi variabel Persepsi Harga terhadap peningkatan penjualan dimediasi Loyalitas pelanggan dikatakan Non Mediation. Variabel kualitas pelayanan terhadap peningkatan penjualan dimediasi Loyalitas pelanggn dikatakan Full Mediation. Variabel Customer Relationship Marketing dan Kepercyaaan terhadap peningkatan penjualan dimediasi Loyalitas pelanggan dikatakan Parsial Mediation
\end{abstract}

Kata Kunci Persepsi Harga, Kualitas Pelayanan, Customer Relationship Marketing, Peningkatan Penjualan Dan Loyalitas Pelanggan. SEM PLS 


\section{PENDAHULUAN}

Pada era 4.0 persaingan dalam dunia usaha semakin tinggi, semua pelaku usaha berlomba untuk meningkatkan penjualan usahanya.usaha mikro, kecil dan menengah misalnya.UMKM merupakan tulang punggung ekonomi nasional sekaligus juga roda perputaran ekonomi dalam Indonesia. Otomatis banyaknya usaha yang dibangun akan menimbulkan permasalahan yang pasti dialami setiap pelaku usaha, salah satunya adalah masalah pemasaran. Oleh karena itu, para pelaku usaha dituntut untuk terus melakukan strategi, inovasi maupun trobosan yang mampu bersaing dengan zaman yang semakin modern ini. Zaman modern mengharuskan para pelaku usaha, khususnya usaha bahan pokok juga melakukan berbagai perubahan dalam sistem pemasaranya. Seperti cara pemesanan Online dan sistem pembayaran langsung / Cash On Delivery (COD), Salah satu usaha yang telah menjalankan strategi ini yaitu usaha Ayam Potong Online ELMONSU.

Strategi pemasaran adalah hal yang paling penting untuk keberlangsungan hidup usaha, karena dengan strategi yang matang akan memudahkan para pelaku usaha untuk memasarkan berbagai produk. Berbagai jenis strategi yang digunakan para pelaku usaha tentunya bertujuan untuk meningkatkan penjualan. Para pelaku usaha pastinya ingin usaha yang dijalankannya mempunyai peningkatan dalam penjualannya. Dengan melihat langsung kebutuhan pasar dan menentukan target pasar yang cocok untuk usaha ayam potong Online ini. Faktor utama yang menjadi penentu meningkatan penjualan yakni pembelian ulang atau loyalitas pelanggan.

Menurut Berry dalam Tjiptono, Fandy (2014:13) Loyalitas dapat didefinisikan sebagai keterikatan antara janji dan komitmen yang dipegang teguh untuk keberlangsungan relasi dan biasanya terjadi dalam pembelian ulang yang bertahan. Loyalitas dapat dibangun oleh seorang wirausaha dengan berbagai cara salah satunya yakni dengan pemberian harga yang ekonomis.

Banyaknya persepsi konsumen yang mengira harga akan mempengaruhi kualitas barang yang dijual berpengaruh pada penjualan Ayam Potong Online ELMONSU, karena usaha ini memberikan harga yang lebih rendah daripada harga dipasaran, tidak sedikit yang menganggap usaha ini mempuyai kualitas yang kurang baik. Bukan hanya harga saja yang dipertimbangkan oleh konsumen, kualitas pelayanan juga diprioritaskan.

Kualitas pelayanan adalah penilaian konsumen terhadap pelayanan dari perilaku usaha sesuai dengan apa yang diharapan, apabila semua pelayanan yang diberikan pemilik sesuai dengan harapan, maka kualitas pelayanan dapat dikatan layak. (Kotler et al, 2014 : 428). Usaha Ayam Potong Online ELMONSU ini juga sangat memperhatikan kualitas pelayanan, baik dari segi pelayanan komunikasi melalui media sosial maupun komunikasi secara langsung. Keramahan kurir Ayam Potong Online ELMONSU juga akan mendapatkan nilai plus dari pelanggan, sehingga menggiring opini masyarakat untuk ikut membeli di usaha ayam potong ini. Ketika kualitas pelayanan sudah terbangun dengan efisien, yang dilakukan pemilik usaha yakni menjaga hubungan dengan konsumen untuk waktu yang cukup panjang yakni dengan strategi Customer Reliationship Marketing.

Customer Relationship Marketing yaitu strategi yang menjaga hubungan jangka panjang antara pelanggan dengan pemilik usaha untuk menciptakan nilai lebih, sehingga dapat mempertahankan serta menambah pangsa pasar dan meningkatkan loyalitas pelanggan. ( Buttle dalam Ningsih et al. 2016 : 172 ). Usaha ayam potong Online ELMONSU juga membangun hubungan yang baik kepada pelanggan seperti selalu berkomunikasi dengan baik. Setelah merasa cocok dengan harga, kualitas pelayanan dan 
juga customer Relationship Marketing, konsumen tentunya akan merasa timbul rasa percaya kepada usaha yang dijalankan.

Kepercayaan dapat diartikan sebagai seluruh keyakinan atas pengetahuan yang dimiliki konsumen dan membuat kesimpulan menurut pemikirannya sendiri.( Mowen et al, 2017: 23). Kepercayan pada usaha ini yakni dengan bukti bahwa pemotongan ayam dilakukan setiap pagi pastinya membuat pelanggan percaya bahwa Ayam Potong Online ELMONSU dijamin kualitas kesegarannya. Ini juga menjadi faktor penambah loyalitas pelanggan terhadap penjualan.

Diantara beberapa jurnal yang telah terpublish oleh Lestari (2018), Devi terdapat 2 variabel yakni Customer Relationship Marketing dan loyalitas pelanggan; Budi, Ugeng (2019) terdapat 3 variabel yakni kualitas pelayanan, kepuasan pelanggan dan loyalitas pelanggan; Shasa, Dwi (2016) terdapat 3 variabel yakni kepercayaan,kepuasan dan loyalitas pelanggan; Budiasari, Sita (2016) terdapat 4 variabel yakni kualitas produk, persepsi harga, citra merek dan loyalitas pelanggan; Nilam, Putri (2020) terdapat 3 variabel yakni pengaruh harga, kualitas pelayanan dan peningkatan penjualan. Dari penjabaran jurnal diatas terdapat kebaruan dalam penelitian ini yaitu penambahan variabel sehingga menjadi 6 yakni persepsi harga, kualitas pelayanan, Customer Relationship Marketing kepercayaan Peningkatan penjualan dan loyalitas

pelanggan, dimana salah satu variabel dijadikan sebagai variabel mediasi atau perantara antara variabel independen dan variabel dependen.

\section{LANDASAN TEORI}

\section{Persepsi Harga}

Persepsi Harga merupakan bentuk penilaian konsumen terhadap barang atau jasa yang dijual dan bentuk emosional yang tersosialisasi mengenai apakah harga sesuai dengan kualitas barang. menurut Kotler et al dalam Muharom et al(2017) Indikator dari persepsi harga yakni : Kesesuaian harga terhadap kualitas produk, Kesesuaian harga terhadap manfaat, Harga yang bersaing

\section{Kualitas pelayanan}

Kualitas Pelayanan adalah suatu penilaian konsumen terhadap pemberian layanan yang dilakukan oleh penjual dengan harapan sesuai keinginan konsumen menurut Kotler et al (2017) Indikatornya adalah : Bukti fisik, Reliabilitas, Daya tanggap, Jaminan dan empati.

\section{Customer Relationship Marketing}

CRM merupakan suatu proses pengolahan informasi secara terperinci tentang bagaimana pelanggan untuk memperoleh loyalitas yang puas. Indikator CRM (X3) menurut Kotler et al dalam Iriandini et al (2015:2) adalah dentifikasi,

Individualisme Interaksi hubungan dengan pelanggan, Integrasi pemilik usaha dengan konsumen.

\section{Kepercyaan}

Kepercayaan adalah suatu keyakinan konsumen dengan pihak produsen bahwa tindakan tersebut merupakan hal yang baik bagi dirinya.Indikator Kepercayaan menurut Mayer et al (2014:67) yaitu : Kejujuran, Kepedulian dan Kredibilitas 


\section{Loyalitas pelanggan}

Loyalitas pelanggan merupakan suatu komitmen konsumen terhadap suatu merek, toko atau pasokan dengan memperhatikan beberapa aspek positif dalam pembelian berjangka panjang. indicator Loyalitas Pelanggan menurut Tjiptono, Fandy (2016: 47) yaitu : Pembelian ulang, Kebiasaan, Keyakinan dan Konsisten.

\section{Peningkatan penjualan}

Peningkatan penjualan adalah penjualan bersih yang diakuisisi dari laporan laba perusahaan dari seluruh penjualan dalam jangka waktu tertentu dengan peningkatan. indicator Peningkatan penjualan menurut Swasta, Basu et al (2008: 4) yaitu :Keanekaragaman produk, Kualitas, Pelayanan dan Garansi dan imbalan

\section{METODOLOGI PENELITIAN}

Jenis penelitian yang digunakan adalah pendekatan Kuntitatif menggunakan skala Likert dan populasi yang diambil dari pembeli ayam potong online ELMONSU dengan jumlah sampel 131 Dengan metode yang digunakan untuk menganalisis yaitu SEM dengan alat Smart PLS versi 3.0. Uji yang digunakan adalah uji Outer Model, Uji Inner Model, Uji Mediasi dan Uji Hipotesis.

\section{HASIL PENELITIAN}

\section{MODEL PENGUKURAN (Outer Model)}

Dalam uji ini terdapat dua model pengukuran yang digunakan yaitu Uji Validitas dan Reliabilitas.

\section{a) Uji Convergent Validity}

Uji ini digunakan untuk mengetahui kesesuian setiap hubungan indicator. pengukuran ini dianggap cukup apabila nilai loading faktor diatas 0,7 dan nilai AVE diatas 0,5

Tabel 1 Uji Convergent Validity

\begin{tabular}{|c|c|c|c|c|}
\hline Variabel & Indikator & $\begin{array}{c}\text { Outer } \\
\text { Loading }\end{array}$ & AVE & \\
\hline \multirow{3}{*}{$\begin{array}{c}\text { Persepsi } \\
\text { Harga (X1) }\end{array}$} & X1.1 & 0.894 & \multirow{3}{*}{0.847} & VALID \\
\hline & $\mathrm{X} 1.2$ & 0.925 & & VALID \\
\hline & $\mathrm{X} 1.3$ & 0.942 & & VALID \\
\hline \multirow{5}{*}{$\begin{array}{l}\text { Kualitas } \\
\text { Pelayanan } \\
\text { (X2) }\end{array}$} & $\mathrm{X} 2.1$ & 0.807 & \multirow{5}{*}{0.690} & VALID \\
\hline & $\mathrm{X} 2.2$ & 0.807 & & VALID \\
\hline & $\mathrm{X} 2.3$ & 0.844 & & VALID \\
\hline & X2.4 & 0.846 & & VALID \\
\hline & X2.5 & 0.848 & & VALID \\
\hline \multirow{4}{*}{$\begin{array}{c}\text { Customer } \\
\text { Relationship } \\
\text { Marketing } \\
(X 3)\end{array}$} & X3 .1 & 0.763 & \multirow{4}{*}{0.685} & VALID \\
\hline & X3 .2 & 0.870 & & VALID \\
\hline & X3 .3 & 0.821 & & VALID \\
\hline & X3.4 & 0.852 & & VALID \\
\hline \multirow{3}{*}{$\begin{array}{c}\text { Kepercayaan } \\
\text { (X4) }\end{array}$} & $\mathrm{X} 4.1$ & 0.811 & \multirow{3}{*}{0.642} & VALID \\
\hline & $\mathrm{X} 4.2$ & 0.779 & & VALID \\
\hline & $\mathrm{X} 4.3$ & 0.813 & & VALID \\
\hline \multirow{6}{*}{$\begin{array}{l}\text { Loyalitas } \\
\text { Pelanggan } \\
\text { (Z) }\end{array}$} & $\mathrm{Z} 1$ & 0.762 & \multirow{4}{*}{0.646} & VALID \\
\hline & $\mathrm{Z} 2$ & 0.790 & & VALID \\
\hline & $\mathrm{Z3}$ & 0.815 & & VALID \\
\hline & $\mathrm{Z4}$ & 0.845 & & VALID \\
\hline & Y1 & 0.835 & \multirow{2}{*}{0.690} & VALID \\
\hline & $\mathrm{Y} 2$ & 0.889 & & VALID \\
\hline
\end{tabular}




\begin{tabular}{|l|c|c|c|c|}
\begin{tabular}{|c|c|c|} 
Peningkatan \\
Penjualan \\
(Y)
\end{tabular} & Y3 & 0.826 & & VALID \\
\cline { 2 - 3 } & Y4 & 0.768 & & VALID \\
\hline
\end{tabular}

Pada uji Convergent Validity variabel Persepsi harga, Kualitas Pelayanan, CRM kepercayaan, Loyalitas pelanggan dan Peningkatan penjualan dinyatakan Valid karena semua nilai diatas 0.7

\section{b) Uji Reliabilitas}

Composite reliability $(\mathrm{Cr})$ dan Cronbach's Alpha Sebuah ukuran yang dihandalkan dengan nilai antara nol sampai satu. Juga dikatakan uji reliabilitas dapat dikatakan Reliable jika nilai yang diperoleh diatas 0,7 .

Tabel 2 Uji Composite Reliability dan Cronbach's Alpha

\begin{tabular}{|l|c|c|c|}
\hline \multicolumn{1}{|c|}{ Variabel } & $\begin{array}{c}\text { Composite } \\
\text { Reliability }\end{array}$ & $\begin{array}{c}\text { Cronbach's } \\
\text { Alpha }\end{array}$ & Keterangan \\
\hline $\begin{array}{l}\text { persepsi } \\
\text { harga }\end{array}$ & 0.943 & 0.910 & Reliabel \\
\hline $\begin{array}{l}\text { Kualitas } \\
\text { Pelayanan }\end{array}$ & 0.918 & 0.889 & Reliabel \\
\hline CRM & 0.896 & 0.847 & Reliabel \\
\hline Kepercayaan & 0.843 & 0.741 & Reliabel \\
\hline $\begin{array}{l}\text { Loyalitas } \\
\text { Pelanggan }\end{array}$ & 0.879 & 0.819 & Reliabel \\
\hline $\begin{array}{l}\text { Peningkatan } \\
\text { Penjualan }\end{array}$ & 0.899 & 0.856 & Reliabel \\
\hline
\end{tabular}

Sumber : Data Primer Diolah (2021)

Pada uji Reliabilitas nilai pada Composite reliability (Cr) dan Cronbach's Alpha variabel Persepsi harga, Kualitas Pelayanan, CRM kepercayaan, Loyalitas pelanggan dan Peningkatan penjualan dinyatakan Valid karena semua nilai diatas 0.7

\section{Model Struktural (Inner model)}

InnerImodel merupakan model yang digunakan untuk menebak sebab akibat hubungan antar variabel laten.

\section{R-Square}

R-Square merupakan uji yang digunakan untuk memperlihatkan seberapa jauh pengaruh hubungan variabel X terhadap variabel Y, menurut Ghozali, Imam (2006:59) jika nilai R-Square 0,67 maka bisa dikatakan kuat, nilai 0,33 dikatakan moderat dan nilai 0,19 dikatakan lemah

Tabel 3 Uji R-Square

\begin{tabular}{|c|c|c|}
\hline Variabel & R Square & R Square Adjusted \\
\hline LOYALITAS & 0.326 & 0.305 \\
\hline $\begin{array}{l}\text { PENINGKATAN } \\
\text { PENJUALAN }\end{array}$ & 0.541 & 0.522 \\
\hline
\end{tabular}

Pada uji dari R-Square berpengaruh secara bersama-sama $\mathrm{X} 1, \mathrm{X} 2, \mathrm{X} 3$ dan $\mathrm{X} 4$ terhadap Y adalah sebesar 0.541 dengan nilai R-Square Adjusted 0.522 maka dikatakan Moderat. 


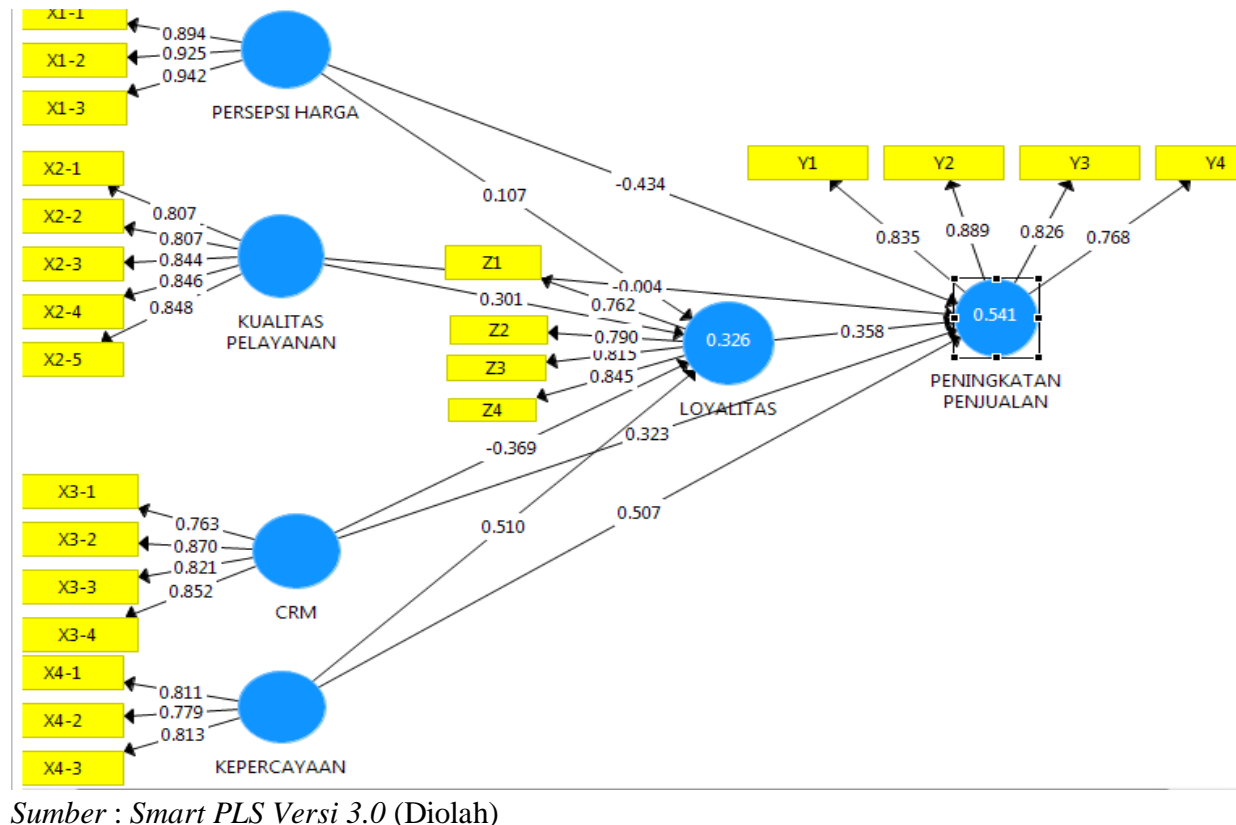

\section{Uji Mediasi}

Terdapat 3 pengelompokan dalam mediasi yakni Non Mediation jika hubungan antar variabel Eksogen dan Endogen positif dan variabel mediasi negatif, Full Mediation terjadi jika variabel Eksogen dan Endogen negatif dan variabel mediasi positif , Parsial Mediation terjadi jika variabel Eksogen dan Endogen positif dan variabel mediasi juga positif. Juga dapat dilihat jika P Value pada Spesific Indirect Effect $>0.05$ bernilai Negatif dan sebaliknya

\begin{tabular}{|c|c|c|c|c|c|}
\hline Variabel & $\begin{array}{l}\text { Original } \\
\text { Sampel }\end{array}$ & $\begin{array}{c}\text { Sampel } \\
\text { Mean }\end{array}$ & $\begin{array}{l}\text { Standart } \\
\text { Deviation }\end{array}$ & $\begin{array}{c}\mathbf{T} \\
\text { Statistik }\end{array}$ & P Value \\
\hline $\begin{array}{l}\text { persepsi harga } \\
\text {-peningkatan } \\
\text { penjualan }\end{array}$ & -0.434 & -0.425 & 0,106 & 4.113 & 0.000 \\
\hline $\begin{array}{c}\text { kualitas } \\
\text { pelayanan - } \\
\text { peningkatan } \\
\text { penjualan }\end{array}$ & -0.004 & 0.032 & 0.178 & 0.020 & 0.492 \\
\hline $\begin{array}{c}\text { CRM - } \\
\text { Peningkatan } \\
\text { penjualan }\end{array}$ & 0.323 & 0.291 & 0.164 & 1.962 & 0.025 \\
\hline $\begin{array}{l}\text { kepercayaan- } \\
\text { peningkatan } \\
\text { penjualan }\end{array}$ & 0.507 & 0.485 & 0.153 & 3.320 & 0.000 \\
\hline \multirow[t]{2}{*}{$\begin{array}{c}\text { persepsi harga } \\
\text { - Loyalitas } \\
\text { pelanggan }\end{array}$} & 0.107 & 0.092 & 0.161 & 0.668 & 0.252 \\
\hline & 0.301 & 0.287 & 0.164 & 1.835 & 0.034 \\
\hline
\end{tabular}




\begin{tabular}{|c|c|c|c|c|c|}
$\begin{array}{c}\text { kualitas } \\
\text { pelayanan - } \\
\text { loyalitas }\end{array}$ & -0.369 & -0.349 & 0.174 & 2.117 & 0.017 \\
\hline $\begin{array}{c}\text { CRM - } \\
\text { Loyalitas }\end{array}$ & 0.510 & 0.531 & 0.124 & 4.117 & 0.000 \\
\hline $\begin{array}{c}\text { kepercayaan - } \\
\text { Loyalitas }\end{array}$ & 0.358 & 0.380 & 0.142 & 2.524 & 0.006 \\
\hline $\begin{array}{c}\text { Loyalitas - } \\
\text { Peningkatan } \\
\text { penjualan }\end{array}$ & 0.50 & & \\
\hline
\end{tabular}

Sumber : Smart PLS Versi 3.0 (Diolah)

Tabel 5 Spesific Indirect Effect

\begin{tabular}{|c|c|c|c|c|c|}
\hline Variabel & $\begin{array}{c}\text { Original } \\
\text { Sampel }\end{array}$ & $\begin{array}{c}\text { Sampel } \\
\text { Mean }\end{array}$ & $\begin{array}{c}\text { Standart } \\
\text { Deviation }\end{array}$ & T Statistik & P Value \\
\hline $\begin{array}{c}\text { persepsi } \\
\text { harga=>loyalit } \\
\text { as=>peningkat } \\
\text { an penjualan }\end{array}$ & 0.038 & 0.027 & 0.062 & 0.622 & 0.267 \\
\hline $\begin{array}{c}\text { kualitas } \\
\text { pelayanan=> } \\
\text { loyalitas=> } \\
\text { peningkatan } \\
\text { penjualan }\end{array}$ & 0.108 & 0.099 & 0.064 & 1.69 & 0.046 \\
\hline $\begin{array}{c}\text { CRM=> } \\
\text { loyalitas=> } \\
\text { peningkatan } \\
\text { penjualan }\end{array}$ & -0.132 & -0.119 & 0.063 & 2.101 & 0.018 \\
\hline $\begin{array}{c}\text { kepercayaan=> } \\
\text { loyalitas=> } \\
\text { peningkatan } \\
\text { penjualan }\end{array}$ & 0.182 & 0.209 & 0.105 & 1.729 & 0.042 \\
\hline
\end{tabular}

Sumber : Smart PLS Versi 3.0 (Diolah)

Dari hasil tersebut dapat disimpulkan bahwa :

\section{Variabel Persepsi Harga Terhadap Peningkatan Penjualan Dimediasi Loyalitas} Pelanggan

Pada tabel 5.14 Path Coeficien variabel persepsi harga terhadap peningkatan penjualan menunjukkan hubungan yang positif karena $\mathrm{P}$ Value $=0.000<0.05$, dan pada tabel 5.15 Specific Indirect Effect Variabel persepsi harga terhadap peningkatan penjualan dimediasi loyalitas pelanggan terjadi hubungan negatif karena $\mathrm{P}$ Value $=0.276$ yang artinya $>0.05$. Maka dalam hubungan ini dapat disebut sebagai Non Mediation. Variabel Kualitas Pelayanan Terhadap Peningkatan Penjulan Dimediasi Loyalitas Pelanggan 
Pada tabel 5.14 Path Coeficien variabel kualitas pelayanan terhadap peningkatan penjualan menunjukkan hubungan negatif karena $\mathrm{P}$ Value $=0.492>0.05$, dan pada tabel 5.15 Specific Indirect Effect Variabel kualitas pelayanan terhadap peningkatan penjualan dimediasi Loylitas Pelanggan terjadi hubungan Positif karena P Value $=0.046$ yang artinya $<0.05$. Maka dalam hubungan ini dapat disebut sebagai Full Mediation

\section{Variabel Customer Realationship Marketing Terhadap Peningkatan Penjualan} Dimediasi Loyalitas Pelanggan

Pada tabel 5.14 Path Coeficien variabel Customer Reliationship Marketing terhadap peningkatan penjualan menunjukkan hubungan yang positif karena $\mathrm{P}$ Value $=$ $0.025<0.05$, dan pada tabel 5.15 Specific Indirect Effect Variabel Customer Reliationship Marketing terhadap peningkatan penjualan dimediasi Loyalitas Pelanggan terjadi hubungan yang positif karena $\mathrm{P}$ Value $=0.018$ yang artinya $>0.05$. Maka dalam hubungan ini dapat disebut sebagai Parsial Mediation

\section{Variabel Kepercayaan Terhadap Peningkatan Penjualan Dimediasi Loyalitas Pelanggan}

Pada tabel 5.14 Path Coeficien variabel Kepercayaan terhadap peningkatan penjualan menunjukkan hubungan yang positif karena $\mathrm{P}$ Value $=0.000<0.05$, dan pada tabel 5.15 Specific Indirect Effect Variabel Kepercayaan terhadap peningkatan penjualan terjdi hubungan yang positif karena $\mathrm{P}$ Value $=0,042$ yang artinya $<0.05$. Maka dalam hubungan ini dapat disebut sebagai Parsial Mediation

\section{Uji Hipotesis}

Uji hipotesis ini dilakukan dengan melihat T-statistik dan $\mathrm{P}$ value. Hipotesis ini dapat diterima apabila $\mathrm{P}$ value $<0.05$. pada penelitian ini ada pengaruh langsung dan tidak langsung karena terdapat variabel eksogen, endogen dan mediasi pada program PLS.

Tabel 6 Uji Hipotesis

\begin{tabular}{|c|c|}
\hline & \\
\hline Hipotesis & Analisis \\
\hline \multirow{5}{*}{$\begin{array}{l}\text { Persepsi Harga } \\
\Rightarrow>\text { Peningkatan } \\
\text { penjualan }\end{array}$} & Nilai Koefisien $=-0.434$ \\
\hline & $\mathrm{P}$ Value $=0.000$ \\
\hline & T-statistik $=4.113$ \\
\hline & $\mathrm{T}$ - Tabel $=1.656$ \\
\hline & T-Statistik > T-Tabel \\
\hline \multirow{5}{*}{$\begin{array}{c}\text { Kualitas } \\
\text { Pelayanan=> } \\
\text { Peningkatan } \\
\text { Penjualan }\end{array}$} & Nilai Koefisien $=-0.004$ \\
\hline & $\mathrm{P}$ Value $=0.492$ \\
\hline & T-statistik $=0.020$ \\
\hline & $\mathrm{T}-$ Tabel $=1.656$ \\
\hline & T-Statistik $<$ T-Tabel \\
\hline \multirow{5}{*}{$\begin{array}{l}\text { CRM => } \\
\text { Peningkatan } \\
\text { Penjualan }\end{array}$} & Nilai Koefisien $=0.323$ \\
\hline & $\mathrm{P}$ Value $=0.025$ \\
\hline & T-statistik $=1.962$ \\
\hline & $\mathrm{T}-$ Tabel $=1.656$ \\
\hline & T-Statistik > T-Tabel \\
\hline \multirow{4}{*}{$\begin{array}{c}\text { Kepercayaan => } \\
\text { Peningkatan } \\
\text { Penjualan }\end{array}$} & Nilai Koefisien $=0.507$ \\
\hline & $\mathrm{P}$ Value $=0.000$ \\
\hline & T-statistik $=3.320$ \\
\hline & T- Tabel 1.656 \\
\hline
\end{tabular}




\begin{tabular}{|c|c|}
\hline & T-Statistik > T-Tabel \\
\hline \multirow{5}{*}{$\begin{array}{l}\text { Persepsi Harga } \\
\Rightarrow>\text { Loyalitas } \\
\text { pelanggan }\end{array}$} & Nilai Koefisien $=0.107$ \\
\hline & $\mathrm{P}$ Value $=0.252$ \\
\hline & T-statistik $=0.668$ \\
\hline & $\mathrm{T}-$ Tabel $=1.656$ \\
\hline & T-Statistik $<\mathrm{T}$-Tabel \\
\hline \multirow{5}{*}{$\begin{array}{c}\text { Kualitas } \\
\text { Pelayanan => } \\
\text { Loyalitas } \\
\text { Pelanggan }\end{array}$} & Nilai Koefisien $=0.301$ \\
\hline & $\mathrm{P}$ Value $=0.034$ \\
\hline & T-statistik $=1.835$ \\
\hline & $\mathrm{T}-$ Tabel $=1.656$ \\
\hline & T-Statistik > T-Tabel \\
\hline \multirow{5}{*}{$\begin{array}{l}\text { CRM }=> \\
\text { Loyalitas } \\
\text { Pelanggan }\end{array}$} & Nilai Koefisien $=-0.369$ \\
\hline & $\mathrm{P}$ Value $=0.017$ \\
\hline & T-statistik $=2.117$ \\
\hline & $\mathrm{T}-\mathrm{Tabel}=1.656$ \\
\hline & T-Statistik > T-Tabel \\
\hline \multirow{5}{*}{$\begin{array}{c}\text { Kepercayaan }=> \\
\text { Loyalitas } \\
\text { Pelanggan }\end{array}$} & Nilai Koefisien $=0.510$ \\
\hline & $\mathrm{P}$ Value $=0.000$ \\
\hline & T-statistik $=4.117$ \\
\hline & $\mathrm{T}-$ Tabel $=1.656$ \\
\hline & T-Statistik > T-Tabel \\
\hline \multirow{5}{*}{$\begin{aligned} & \text { Loyalitas } \\
\Rightarrow>\text { Peningkatan } & \text { Penjualan }\end{aligned}$} & Nilai Koefisien $=0.358$ \\
\hline & $\mathrm{P}$ Value $=0.006$ \\
\hline & T-statistik $=2.524$ \\
\hline & $\mathrm{T}-$ Tabel $=1.656$ \\
\hline & T-Statistik > T-Tabel \\
\hline
\end{tabular}

\section{PEMBAHASAN}

\section{Hipotesis 1: Persepsi Harga terhadap peningkatan penjualan}

menunjukkan bahwa nilai Koefisien sebesar $-0.434<0.000$ dengan T-statistik $>$ T-tabel $(4.11>1.656)$ dan $\mathrm{P}$ value $0.000<0.05$ maka H0 ditolak dan Ha1 diterima, artinya terdapat pengaruh negatif dan signifikan. Terjadi arah hubungan yang negatif karena banyaknya konsumen mengira bahwa harga di Ayam potong online ELMONSU ini lebih diatas rata-rata daripada harga pasar karena mempunyai sistem COD yang menurut konsumen memungkinkan untuk menambah harga yang sudah ditetapkan, konsumen juga berpendapat bahwa kesesuaian harga ayam yang dijual akan mempengaruhi kualitas barang. Pada ayam ELMONSU ini memberikan harga yang lebih rendah dari pasar sehingga konsumen berpendapat bahwa kualitas dari ayam ELMONSU ini kurang baik. Hal ini juga didukung dengan penelitian yang dilakukan oleh Nilam, Putri (2020) yang menunjukan bahwa persepsi harga mempunyai pengaruh negatif dan signifikan terhadap peningkatan penjualan. 


\section{Hipotesis 2: Kualitas pelayanan terhadap peningkatan penjualan}

Menunjukkan bahwa nilai Koefisien sebesar $-0.004<0.000$ dengan T-statistik $<$ T-tabel $(0.020<1.656)$ dan P-value $0.492>0.05$ maka H0 diterima dan Ha2

ditolak, artinya terdapat pengaruh negatif dan tidak signifikan. karena pemilik yang selalu fast respond, adanya pelanggan Ayam ELMONSU yang tidak terlayani dengan cepat karena faktor lain dari pemilik seperti kurang cepatnya membalas WhatApp misalnya memesan pada waktu dini hari. Juga ketersediaan semua kondimen ayam yang kurang lengkap seperti banyaknya peminat pelangan terhadap barang yang langka seperti telur muda, pelanggan merasa kurang puas karena barang ini cepat habis diburu pelanggan,Terdapathasil lain dari penelitian yang dilakukan oleh Nilam, Putri (2020) yang menunjukkan bahwa kualitas pelayanan berpengaruh positif secara simultan terhadap peningkatan penjualan.

\section{Hipotesis 3: CRM terhadap peningkatan penjualan}

Menunjukkan bahwa nilai Koefisien sebesar $0.323>0.000$ dengan T-statistik $>$ T-tabel $(1.962>1.656)$ dan P-value $0.025<0.05$ maka H0 ditolak dan Ha3 diterima, artinya terdapat pengaruh positif secara signifikan. Berpengaruh positif secara signifikan karena pemilik Ayam Potong Online ELMONSU selalu membangun hubungan yang baik terhadap semua pelanggannya, juga didukung dengan hubungan dari kurir yang selalu menerapkan prinsip sopan, santun dan senyum. Bukan hanya hubungan secara langsung saja yang diberikan tetapi juga menerima semua saran yang diberikan pelanggan seperti memperbaiki sistem pemesanan yang dulunya Close order pukul 05.30 WIB menjadi 06.00 WIB. Hasil ini juga didukung oleh penelitian Wiliam, Wendy (2020) yang menunjukkan bahwa CRM berpengaruh positif terhadap peningkatan penjualan pada PT CIPTA ANEKA BUAH.

\section{Hipotesis 4: Kepercayaan terhadap peningkatan penjualan}

Menunjukkan bahwa nilai Koefisien sebesar $0.507>0.000$ dengan T-statistik $>$ T-tabel $(3.320>1.656)$ dan P-value $0.000<0.05$ maka H0 ditolak dan Ha4 diterima, artinya terdapat pengaruh positif secara signifikan. Berpengaruh positif secara signifikan karena semua pelanggan percaya bahwa Ayam Potong Online ELMONSU ini termasuk usaha yang amanah, dari segi kualitas yang sudah terjamin halal karena proses pemotongan yang sesuai dengan aturan Islam dan pemotongan dilakukan setiap pagi, ini memastikan bahwa ayam ELMONSU adalah ayam yang selalu fresh dan sehat. juga dari segi waktu pengantaran kepada pembeli diusahakan sedisiplin mungkin, selalu tepat waktu sesuai dengan permintaan pelanggan, karena kepercayaan pelanggan inilah yangmenjadikan penjualan meningkat. Hasil ini didukung oleh penelitian dari Yuniawan, Ahyar (2016) bahwa terdapat pengaruh positif dan signifikan variabel kep ercayaan terhadap peningkatan penjualan pada studi kasus bubur bayi Promina.

\section{Hipotsis 5: Persepsi harga terhadap loyalitas pelanggan}

Menunjukkan bahwa nilai Koefisien sebesar $0.107>0.000$ dengan T-statistik < T-tabel $(0.668<1.656)$ dan P-value 0.252> 0.05 maka H0 diterima dan Ha5 ditolak, artinya terdapat pengaruh positif tetapi tidak signifikan. Berpengaruh positif tetapi tidak signifikan karena semua konsumen telah mengetahui harga ayam secara umum, maka para pembeli Ayam Potong Online ELMONSU ini tidak mempunyai dugaan terhadap harga, konsumen berpendapat bahwa semua harga ayam ELMONSU lebih tinggi dari harga rata-rata karena kualitas yang berikan lebih daripada penjual ayam 
lainnya. Dari persepsi harga tersebut maka konsumen mempunyai pendapat bahwa Harga ayam ELMONSU kurang cocok untuk sebuah usaha atau dijual kembali. hanya yang membedakan adalah kecepatan dalam pengirimannya.Terdapat perbedaan penelitian yang dilakukan oleh Ayu, Ida (2020) terdapat pengaruh positif dan signifikan antara persepsi harga dengan loyalitas pelanggan.

\section{Hipotesis 6:Kualitas pelayanan terhadap loyalitas pelanggan}

Menunjukkan bahwa nilai Koefisien sebesar $0.301>0.000$ dengan T-statistik > T-tabel $(1.835>1.656)$ dan P-value $0.034<0.05$ maka H0 ditolak dan Ha6 diterima, artinya terdapat pengaruh positif secara signifikan. Berpengaruh positif secara signifikan karena ketepatan waktu yang diberikan oleh Ayam potong online ELMONSU ini selalu menjadi kunci utama dari pemilik untuk mendapatkan pembelian ulang dari para konsumen, juga selalu menanyakan barang yang telah sampai ditangan pembeli sesuai dengan barang yang telah dipesan, misalnya potongan sesuai dengan pesanan dan juga kelengkapan dari kondimen yang dipesan. Artinya pemilik selalu bertanggung jawab atas barang yang dijualnya... Penelitian dengan hasil tersebut didukung oleh penelitian dari Zahrah, Fakhrana (2020) yang menunjukkan bahwa kualitas pelayanan berpengaruh positif dan signifikan terhadap kepuasan dan loyalitas pelanggan.

\section{Hipotesis 7: CRM terhadap loyalitas pelanggan}

Menunjukkan bahwa nilai Koefisien sebesar $-0.369<0.000$ dengan T-statistik $>$ T-tabel $(2.117>1.656)$ dan P-value $0.017<0.05$ maka H0 ditolak dan Ha7 diterima, artinya terdapat pengaruh Negatif dan Signifikan. Terjadi arah hubungan bersifat negatif tetapi signifikan antara CRM dengan Loyalitas Pelanggan karena menurut konsumen ayam ELMONSU hubungan yang sudah dibangun dengan baik seperti perduli dengan keadaan konsumen ketika mendapatkan musibah tidak mempengaruhi konsumen untuk melakukan pembelian ulang dikarenakan faktor lain seperti rumah konsumen yang dekat dengan pasar. Penelitian ini didukung oleh Harun, Harniza (2016) bahwa Customer Relationship Marketing berpengaruh negatif dan sign ifikan terhadap loyalitas nasabah Bank Muamalat Indonesia.

\section{Hipotesis 8: Kepercayaan terhadap loyalitas pelanggan}

Menunjukkan bahwa nilai Koefisien sebesar $0.510>0.000$ dengan T-statistik $>$ T-tabel $(4.117>1.656)$ dan P-value $0.000<0.05$ maka H0 ditolak dan Ha8 diterima, artinya terdapat pengaruh Positif secara Signifikan. Berpengaruh positif secara signifikan karena Ayam ELMONSU ini tidak pernah memberikan barang yang kurang baik kepada pelanggan, banyaknya konsumen rata-rata adalah pemilik usaha Catering yang pastinya pintar memilih kualitas ayam dan juga harga yang sesuai untuk dijual kembali. Pemilik selalu bertanggung jawab atas barang yang dipesan. jika sudah timbul rasa percaya. secara tidak langsung kepercayaan ini akan membuat konsumen membeli lagi kepada ayam ELMONSU. Hasil tersebut didukung oleh penelitian Shasa, Dwi Harumi (2016) bahwa secara serentak terdapat pengaruh antara kepercayaan dan kepuasan terhadap loyalitas pelanggan.

\section{Hipotesis 9: Loyalitas pelanggan terhadap Peningkatan penjualan}

Menunjukkan bahwa nilai Koefisien sebesar $0.358>0.000$ dengan T-statistik > T-tabel (2.524 > 1.656) dan P-value $0.006<0.05$ maka H0 ditolak dan Ha9 diterima, artinya terdapat pengaruh positif secara signifikan. karena sudah terbukti bahwa kualitas 
ayam ELMONSU ini sudah terjamin halal dan fresh yang pasti tidak diragukan lagi, banyaknya testimoni baik dari pelanggan yang mengatakan bahwa kualitas dari segi barang maupun jasanya sangat memuaskan, pembelian ulang terjadi ketika konsumen merasakan banyaknya kelebihan dari ayam ELMONSU ini dan ketika pembelian ulang memiliki peningkatan secara otomatis penjualan ayam ELMONSU juga meningkat. Hasil tersebut didukung oleh penelitian Putra, Bala (2017) menujukkan bahwa loyalitas pelanggan mempengaruhi peningkatan penjualan pada pelanggan Marketplace Indonesia.

\section{KESIMPULAN}

\section{Model Pengukuran ( Outer Model)}

Pada uji Validitas dan reliabilitas variabel Persepsi harga, Kualitas Pelayanan, Customer Relationship Marketing, kepercayaan, Loyalitas pelanggan dan Peningkatan penjualan dinyatakan Valid dan Reliable karena semua nilai diatas 0.7

\section{Model Structural ( Inner Model )}

Pada uji R-Square variabel Persepsi harga, Kualitas Pelayanan, Customer Relationship Marketing, dan kepercayaan terhadap Peningkatan penjualan dinyatakan Moderat karena nilai R-Square berada diantara 0.33 sampai 0.66

\section{Uji Mediasi}

Pada variabel Persepsi Harga terhadap peningkatan penjualan dimediasi Loyalitas pelanggan dikatakan Non Mediation.Pada variabel kualitas pelayanan terhadap peningkatan penjualan dimediasi Loyalitas pelanggn dikatakan Full Mediation. Pada variabel Customer Relationship Marketing dan Kepercyaaan terhadap peningkatan penjualan dimediasi Loyalitas pelanggan dikatakan Parsial Mediation

\section{Uji Hipotesis}

a) Persepsi harga mempunyai pengaruh negatif dan signifikan terhadap peningakatan penjualan.

b) Kualitas pelayanan mempunyai pengaruh negatif dan tidak signifikan terhadap peningkatan penjualan. peningkatan penjualan.

c) Customer Relationship Marketing mempunyai pengaruh positif secara signifikan terhadap peningkatan penjualan.

d) Kepercayaan mempunyai pengaruh positif secara signifikan terhadap peningkatan penjualan.

e) Persepsi harga tidak mempunyai pengaruh positif tetapi tidak signifikan terhadap loyalitas pelanggan.

f) Kualitas pelayanan mempunyai pengaruh positif dan signifikan terhadap loyalitas pelanggan.

g) Customer Relationship Marketing mempunyai pengaruh negatif dan signifikan terhadap loyalitas pelanggan.

h) Kepercayaan mempunyai pengaruh positif secara signifikan terhadap loyalitas pelanggan.

i) Loyalitas pelanggan mempunyai pengaruh positif secara signifikan terhadap peningkatan penjualan.

\section{DAFTAR PUSTAKA}

Basu,Swasta., Hani, Handoko. 2008. Analisis prilaku konsumen Edisi 1. BPFE. Yogyakarta

Berry .2014. konsep pemasaran : loyalitas Dalam Fandy, Tjiptono. Strategi Pemasaran 
Edisi 3 (hlm.48-53). Andi, Yogyakarta.

Devi lestari pramita putri. 2018. Pengaruh Customer relationship marketing terhadap loyalitas pelanggan XL AXITA Sampang. Jurnal manajemen \& kewirausahaan. Volume III;3-16.

Ghozali, Imam. 2006. Partial least square. Penerbit Universitas Diponegoro. Semarang.

Iriandini.,wachyu. 2015. Customer Relationship Marketing dengan loyalitas. Dalam Kotler, Philip., Keller, Kevin Lane. Manajemen pemasaran. Erlangga. jakarta.

Kotler, Philip., Keller, Kevin Lane. 2014. Manajemen Pemasaran. Erlangga, Jakarta

Mayer, R C., davis J H.,Schoroman. 2014. Perceived usefulness. Andi. Yogyakarta Muharom.,Sholikha. 2017. Pengaruh persepsi harga terhadap konsumen. Dalam Kotler Philip. Manajemen pemasaran. Erlangga. Jakarta

Ningsih,N.,wachyu. 2016. pengaruh customer pelanggan. relationship marketing terhadap loyalitas pelanggan. Dalam Francis Buttle. Customer Relationship Marketing Edisi 3 (hlm 172). Elsevier Publishing, Amsterdam.

Putri Nilam Kencana. 2020. Pengaruh harga dan kualitas pelayanan terhadap volume penjualan pada PT SRIWIJAYA BERKAH INDONESIA. Jurnal ekonomi efektif. Volume 02; 151-155.

Shasa, Dwi Harumi. 2016. PengaruhIkepercayaan dan kepuasan pelangan terhadap loyalitas pelanggan diperusahaan SEIKO LAUNDRY. Jurnal Analitika. Volume $08 ; 115$.

Sita, Budiasari. 2016. Pengaruh kualitas produk, persepsi harga dan citra merek terhadap kepuasan dan loyalitas pelanggan beton siap pakai HOLCHIM. Jurnal media ekonomi \& manajemen. Volume 3; 87-89.

Ugeng Budi Bandoko. 2019. Pengaruh kualitas pelayanan dan kepuasan pelanggan terhadap loyalitas pelanggan pada IRANCH 99 MARKET. Jurnal ekonomi efektif. Volume 2; 161. 